\title{
Effect of dietary protein level and thyroxine on vitamin A depletion from liver in chicks
}

\author{
By I. NIR AND I. ASCARELLI \\ Department of Animal Nutrition and Agricultural Biochemistry, \\ Faculty of Agriculture, Hebrew University, Rehovot, Israel \\ (Received 21 May 1965-Accepted 25 August 1965)
}

\begin{abstract}
I. The effect of dietary protein level and supplementation with thyroxine and thiouracil on depletion of liver stores of vitamin $A$, on the percentage of liver vitamin $A$ in the alcohol form and on the plasma level of vitamin $A$ and protein has been studied in chicks. In an experiment with cockerels the relation was investigated between the vitamin A level of plasma and the electrophoretic pattern of its proteins. 2. Liver vitamin A depletion was considerably reduced by lowering the dietary protein level. 3 . Protein malnutrition lowered the percentage of vitamin A found in the liver in the alcohol form. 4. Depletion of vitamin A from the liver was related to the percentage of vitamin $A$ in the alcohol form. 5. Thyroxine increased both vitamin $A$ depletion from the liver and the percentage of vitamin A in the alcohol form, whereas thiouracil had the opposite effect. 6. Plasma vitamin $A$, and plasma protein contents were significantly lowered in cockerels receiving a $5 \%$ protein diet. The drop in plasma protein level was essentially caused by a reduction of the albumin fraction. No significant change in the levels of globulins was observed even after a 4 -week period of protein malnutrition. 7 . When the dietary protein level was restored to normal both the albumin and vitamin $\mathrm{A}$ levels in plasma increased.
\end{abstract}

The interrelationship between dietary protein level and vitamin A metabolism has attracted the attention of nutritionists for quite a number of years. Already some 25 years ago Basu \& De (I94I) and Baumann, Foster \& Moore (1942) found in rats that with a low level of dietary protein vitamin A storage in liver was reduced, but Dye, Bateman \& Porter (1945) found that the level of dietary protein had only little effect on the utilization of vitamin A by rats.

In more recent work, also on rats, Rechcigl, Berger, Loosli \& Williams (1962) and Deshmukh, Malathi \& Ganguly ( 1964 ) demonstrated that low dietary protein retards liver depletion in rats. Moore, Sharman \& Ward (1952) observed that a liberal allowance of vitamin $A$ increased the resistance of animals to severe deficiency of protein. Esh \& Bhattacharya ( $196 \mathrm{r}$ ) found that body-weight gain increased gradually with increasing vitamin A intake when a suboptimal level of dietary protein or an imbalanced dietary protein was given. This suggests that vitamin $A$ is helpful in improving protein utilization. Deuel, Hrubetz, Johnston, Rollman \& Geiger (1946), Fraps (1946), and James \& Elgindi (1953) also observed a relationship between protein level in the diet and vitamin $A$ metabolism.

It has been suggested that a specific protein carrier is related to vitamin A transport in blood (Ganguly, Krinsky, Mehl \& Deuel, 1952; Krinsky, Cornwell \& Oncley, I958). In more recent work it has been shown that children with kwashiorkor failed to absorb vitamin A (Arroyave, Wilson, Méndez, Béhar \& Scrimshaw, I96r ; Arroyave, Wilson, Contreras \& Béhar, 1963). 
The blood proteins transporting vitamin $\mathrm{A}$ ester and alcohol may behave in the electrophoretic field in the same way as the albumin (Bagchi, Halder \& Chowdhury, 1959). When normal adult rats are maintained on low levels of protein a fall occurs in plasma vitamin A level concomitant with a decrease in albumin level. Protein repletion raises both albumin and vitamin A level in plasma. A similar effect was found in pigs (Friend, Heard, Platt, Stewart \& Turner, 1961).

Reports in the literature on the influence of the thyroid on the utilization of vitamin A and carotene are most contradictory. Johnson \& Baumann (I947) found that after ingestion of carotene liver storage of vitamin A is depressed in hypothyroidism and increased in hyperthyroidism. When preformed vitamin A was used the influence of the thyroid was not evident. Similar findings were reported by Chanda, Clapham, McNaught \& Owen (1952) with cows and goats, and by Cama \& Goodwin (r949) with rats. On the other hand, Arnrich \& Morgan (1954) and Wiese, Mehl \& Deuel (1948) reported that carotene and vitamin A are equally well utilized by normal and hypothyroidic rats. Arnrich \& Morgan (1954) explained the differences in storage of vitamin A by normal and hypothyroidic rats as due to reduction in growth of the latter. Previous work in this laboratory (Ascarelli, Budowski, Nir \& Bondi, 1964) showed that vitamin A storage is increased in thyroxine-fed chicks, the effect being dependent on both the thyroxine and vitamin A level in the diet.

The influence of the thyroid on protein metabolism may partly explain the effect of the thyroid hormones on carotene and vitamin A utilization. Babaev (1963) pointed out that an increase of $\alpha$-glycoproteins with concurrent decrease of $\beta$-glycoproteins in the blood serum was observed in rats with thyrotoxicosis provoked by thyroxine. In rats with hypothyrosis increase in $\alpha$ - and $\beta$-glycoproteins was observed.

Experiments on the incorporation of $\mathrm{DL}-\left[{ }^{14} \mathrm{C}\right]$ leucine and $\mathrm{DL}-\left[{ }^{14} \mathrm{C}\right]$ valine into the protein of cell-free rat liver homogenate demonstrated that some of the apparently conflicting actions of thyroxine on protein synthesis are due to a biphasic effect, i.e. depend on the amount of thyroxine given to the animals during the pretreatment period or on the amount added to the medium in experiments in vitro (Sokoloff \& Kaufman, 1959, 1960, 196r; Sokoloff, Kaufman, Campbell, Francis \& Gelboin, 1963).

In the work now presented we have tested the effect of dietary protein on the depletion of liver vitamin $\mathrm{A}$ in the chick. By adding thyroactive agents to diets of different protein content we have also tried to find whether the changes in vitamin A metabolism caused by the dietary treatments could be explained by the thyroidprotein interrelationship.

\section{EXPERIMENTAL}

\section{Animals and diets}

All chicks were cross-bred New Hampshire $\times$ White Leghorn. They were kept in thermostatically controlled electrically heated batteries equipped with raised wire-mesh floors. The experimental feeding period was preceded by a depletion period of 2 weeks (unless otherwise stated) during which a commercial diet, almost devoid of vitamin A-active ingredients, was given (diet no. 5 of Ascarelli et al. 1964). 
The mean amount of vitamin A after depletion was Io-30 i.u./liver. The compositions of the experimental diets used are given in Table $\mathbf{I}$.

Vitamin A was given by mouth as water-dispersible vitamin A palmitate (Chas Pfizer \& Co. Inc., New York) in a single dose. In order not to affect the absorption of the vitamin, the giving of the depletion diet was continued for $24 \mathrm{~h}$ after dosing. After that period the experimental diets were offered. In the diets of the thyroxinetreated groups a $1 \%$ premix of L-thyroxine in lactose was included in an amount to supply $5 \mu \mathrm{g}$ thyroxine/g diet. In all the experiments the birds were group-fed.

All chicks were killed by bleeding by heart puncture.

Table I. Percentage composition of the diets used in the different experiments

\begin{tabular}{|c|c|c|c|c|c|c|c|c|c|c|c|}
\hline \multirow[b]{2}{*}{ Protein... } & \multicolumn{3}{|c|}{ Expt I } & \multicolumn{4}{|c|}{ Expt 2} & \multicolumn{2}{|c|}{ Expt 3} & \multicolumn{2}{|c|}{ Expt 4} \\
\hline & None & $5 \%$ & $25 \%$ & None & $5 \%$ & $10 \%$ & $20 \%$ & $12.5 \%$ & $25 \%$ & $5 \%$ & $22 \%$ \\
\hline Soya-bean meal & - & 10.0 & $50 \cdot 0$ & - & - & - & - & $20 \cdot 0$ & $40 \cdot 0$ & 10.0 & 44.0 \\
\hline Casein & - & - & - & - & $5 \cdot 0$ & IO.O & $20 \cdot 0$ & - & - & - & - \\
\hline Sorghum & - & - & - & - & - & - & - & $25^{\circ} 0$ & $50 \cdot 0$ & - & - \\
\hline Carbohydrate mixture* & $83 \cdot 0$ & 73.0 & $33 \cdot 0$ & $83 \cdot 0$ & 78.0 & 73.0 & $63 \cdot 0$ & $48 \cdot 5$ & 66.7 & $72 \cdot 7$ & $38 \cdot 3$ \\
\hline Cellulose & 3.0 & 3.0 & $3 \cdot 0$ & $3 \cdot 0$ & 3.0 & $3 \cdot 0$ & $3 \cdot 0$ & - & 一 & $3 \cdot 0$ & 3.0 \\
\hline Soya-bean oil, refined & 10.0 & 10.0 & 10.0 & 10.0 & 10.0 & 10.0 & 10.0 & - & - & $8 \cdot 0$ & 8.0 \\
\hline Mineral mixture & $5 \cdot 9$ & $5 \cdot 9$ & $5 \cdot 9$ & $5 \cdot 9$ & $5 \cdot 9$ & $5 \cdot 9$ & $5 \cdot 9$ & 6.4 & $3 \cdot 2$ & $6 \cdot 0$ & $6 \cdot 0$ \\
\hline Vitamin mixturef & $O \cdot I$ & 0.1 & 0.1 & 0.1 & 0.1 & 0.1 & 0.1 & 0.1 & 0.1 & $0 \cdot 1$ & 0.1 \\
\hline Choline & - & - & - & - & - & - & - & - & - & 0.15 & 0.15 \\
\hline DL-methionine & - & - & - & -- & - & - & - & - & $\ldots$ & 0.1 & 0.44 \\
\hline
\end{tabular}

* Starch $50 \%$ and glucose monohydrate $50 \%$.

† 'To supply $\mathrm{CaHPO}_{4} \cdot \mathrm{H}_{2} \mathrm{O} 2 \cdot 15 \%, \mathrm{CaCO}_{3} \mathrm{I} \cdot 5 \%, \mathrm{NaCl} 0.8 \%, \mathrm{KH}_{2} \mathrm{PO}_{4} 0.9 \%, \mathrm{KHCO}_{3} 0.3 \%$, $\mathrm{MgSO}_{4} 0.25 \%$, Mn as $\mathrm{MnO} 208 \mathrm{ppm}$, I as $\mathrm{KI} 3.8 \mathrm{ppm}, \mathrm{Fe}$ as $\mathrm{FeCO}_{3} 2 \mathrm{ppm}, \mathrm{Cu}$ as $\mathrm{CuCO}_{3} 8 \mathrm{ppm}$, $\mathrm{Co}$ as $\mathrm{CoCO}_{3} 0^{\circ} 64 \mathrm{ppm}, \mathrm{Zn}$ as $\mathrm{ZnO}{ }_{1} 60 \mathrm{ppm}$, Mo as $\mathrm{Na}_{2} \mathrm{MoO}_{4} 3.5 \mathrm{ppm}$.

I To supply per $\mathrm{kg}$ diet: thiamine $5 \mathrm{mg}$, riboflavine $5 \mathrm{mg}$, nicotinic acid $60 \mathrm{mg}$, pantothenic acid $\mathrm{i} 5$ $\mathrm{mg}$, pyridoxine $5 \mathrm{mg}$, folic acid $4 \mathrm{mg}$, biotin $0.2 \mathrm{mg}$, menaphthone $0.5 \mathrm{mg}$, vitamin $B_{12} 20 \mu \mathrm{g}$, $\alpha$-tocopheryl acetate $60 \mathrm{mg}$, vitamin $\mathrm{D}_{3} 5000$ i.u.

Expt x. After 26 days' depletion the chicks were divided into groups of six chicks per treatment. Their mean initial weight was $175 \mathrm{~g}$. The chicks were given 950 i.u. vitamin A palmitate in Expt I A and I200 i.u. in Expt $\mathrm{I}$ B. The experimental period was $I$ week in Expt I A and 2 weeks in Expt I B. During this period a protein-free diet and diets containing 5 or $25 \%$ protein were offered.

Expt 2. Two-week-old chicks of $124 \mathrm{~g}$ mean weight were divided into groups. They were given a single dose of 4500 i.u. water-dispersible vitamin A palmitate and then offered a protein-free diet or diets containing 5, Io or $20 \%$ 'vitamin free' casein (Nutritional Biochemical Corporation, Cleveland, Ohio), without supplement or supplemented with thyroxine. Six chicks receiving each of the three lowest protein levels and twelve chicks receiving the $20 \%$ protein level were killed after 1 or after 2 weeks.

Expt 3. This was a $2 \times 3$ factorial experiment in which two levels of protein $(25 \%$ and $12.5 \%$ ) were used either without any supplement or supplemented by thyroxine or thiouracil. Equalization of food consumption was achieved by pair-feeding the groups on the $25 \%$ protein level with the control group on the $12.5 \%$ protein level. The groups receiving the $12.5 \%$ protein level and treated with thyroxine or thiouracil 
were fed ad lib. as their food consumption was even lower than that of their control groups. Each treatment was given to a group of twenty chicks and their mean initial liver store of vitamin A was $\mathrm{I} 373$ i.u.

Expt 4. Chicks depleted of their vitamin A stores during 2 weeks were maintained on the basal diet supplemented with 75 i.u. vitamin $\mathrm{A} / \mathrm{roO} \mathrm{g}$ diet up to the age of 8 weeks. (In an earlier experiment it was found (unpublished results) that under these conditions normal growth was achieved but no vitamin $A$ was stored in the liver.) The mean weight of the cockerels was then $950 \mathrm{~g}$. They were given a single dose of 10000 i.u. vitamin A palmitate by mouth. Their mean initial liver store of vitamin A was 6487 i.u. Chicks on treatments $I$ and 3 received $22 \%$ and $5 \%$ protein in their diet respectively during the experimental period. Those on treatment 2 received $5 \%$ during the first 2 weeks and $22 \%$ during the 2 following weeks. Electrophoresis of blood plasma was carried out. It was therefore possible to study the effects of a very low level of dietary protein and of giving protein-depleted animals a diet with a normal protein level, on both the plasma protein picture and the plasma vitamin A level.

\section{Analytical methods}

Total liver vitamin A ester was measured by the procedure of Ames, Risley \& Harris (1954). When liver vitamin A ester and alcohol were to be determined a portion of the diethyl ether extract obtained by this method was evaporated, taken up in light petroleum and chromatographed through an alumina column by the method described by Thompson, Ganguly \& Kon (1949).

Plasma or serum vitamin A was determined by extraction with light petroleum (boiling range $30-40^{\circ}$ ) after denaturation of the proteins by the addition of an equal volume of ethanol. After a short centrifugation a portion of the extract was transferred to a small $\left(\frac{1}{2}\right.$ in) test tube, evaporated under reduced pressure and dissolved in I ml chloroform. The amount of vitamin A was then determined by the Carr-Price reaction in a total volume of $3 \mathrm{ml}$. Readings were taken in a Bausch \& Lomb Spectronic 20 colorimeter.

Total protein in plasma was determined by the biuret method as described by Gornall, Bardawill \& David (1949). Plasma protein fractions were separated by paper electrophoresis in a horizontal chamber according to Grassman \& Hannig (Grassman, 1956) with a Michaelis buffer, $\mathrm{pH} 8 \cdot 6$. The strips were then dried, dyed with a saturated amido black solution in methanol:glacial acetic acid:water, 45:45:10, washed with the same solvent mixture, and the intensity of the adsorbed dye was determined in a Photovolt densitometer 52-C.

The results of each experiment were subjected to analysis of variance. Significance among the different groups was tested by the Studentized range $q$ test (Federer, 1955).

\section{RESULTS}

Expt $\mathrm{x}$. The results are presented in Table 2. In addition to the obvious effect of protein level on growth, it will be seen that the mobilization of vitamin A from liver and the serum protein level were correlated with the protein content of the diet. In 
this experiment the difference in vitamin A mobilization can be explained on the basis of growth (and maintenance) requirements, but the reduction in mobilization may also be explained, as the following experiments show, by the state of protein deficiency.

Table 2. Expt 1. Effect of dietary protein level on depletion of liver vitamin $A$ and protein level in serum of chicks

(Six chicks/treatment)

\begin{tabular}{|c|c|c|c|c|c|}
\hline \multirow[b]{2}{*}{ Expt } & \multirow{2}{*}{$\begin{array}{c}\text { Dietary } \\
\text { protein } \\
\text { level } \\
(\%)\end{array}$} & \multirow{2}{*}{$\begin{array}{l}\text { Mean final } \\
\text { weight of } \\
\text { chicks } \\
\text { (g) }\end{array}$} & \multicolumn{2}{|c|}{ Total vitamin A content } & \multirow{2}{*}{$\begin{array}{c}\text { Serum } \\
\text { protein } \\
\text { content } \\
(\%)\end{array}$} \\
\hline & & & i.u./liver & SEt & \\
\hline A, I week & $\begin{array}{r}0 \\
5 \\
25\end{array}$ & $\begin{array}{l}138 \\
174 \\
296\end{array}$ & $\left.\begin{array}{c}334 \\
206 \\
44^{*}\end{array}\right\}$ & $5^{8}$ & $\left\{\begin{array}{l}2 \cdot 54 \\
2 \cdot 92 \\
3 \cdot 29\end{array}\right.$ \\
\hline B, 2 weeks & $\begin{array}{r}0 \\
5 \\
25\end{array}$ & $\begin{array}{l}\text { I Io } \\
139 \\
436\end{array}$ & $\begin{array}{c}205 \\
150 \\
13 * *\end{array}$ & 34 & $\left\{\begin{array}{l}2 \cdot 06 \\
2 \cdot 43 \\
3 \cdot 03\end{array}\right.$ \\
\hline
\end{tabular}

* Significantly different from the other treatments at the $5 \%$ level.

** Significantly different from the other treatments at the I \% level.

$\uparrow$ Standard error of the experiment.

Table 3. Expt 2. Effect of protein (casein) level and thyroxine in the diet on total vitamin $A$ content of the liver, percentage of liver vitamin $A$ as free alcohol and plasma protein content of chicks

\begin{tabular}{|c|c|c|c|c|c|}
\hline Treatment & $\begin{array}{c}\text { Dietary } \\
\text { protein } \\
\text { level } \\
(\%)\end{array}$ & $\begin{array}{l}\text { Mean final } \\
\text { weight of } \\
\text { chicks } \\
\text { (g) }\end{array}$ & $\begin{array}{c}\text { Total } \\
\text { vitamin A } \\
\text { in liver } \\
\text { (i.u.) }\end{array}$ & $\begin{array}{c}\text { Vitamin A } \\
\text { alcohol } \\
\text { in liver } \\
(\% \text { of total) }\end{array}$ & $\begin{array}{c}\text { Protein in } \\
\text { plasma } \\
(\%)\end{array}$ \\
\hline \multicolumn{6}{|c|}{ After I week } \\
\hline \multirow[t]{4}{*}{ Control } & 0 & 108 & 2172 & $7 \cdot 2$ & $2 \cdot 75$ \\
\hline & 5 & 109 & 2086 & IO' 3 & 2.77 \\
\hline & ro & 122 & I 862 & $10 \cdot 0$ & $3 \cdot 00$ \\
\hline & 20 & I 26 & I 990 & $16 \cdot 6$ & $2 \cdot 84$ \\
\hline \multirow[t]{4}{*}{ Thyroxine } & 0 & 101 & 2006 & $13 \cdot 0$ & $2 \cdot 23$ \\
\hline & 5 & 102 & 2212 & 10.6 & $2 \cdot 24$ \\
\hline & 10 & I I 4 & I 818 & $9 \cdot 0$ & $2 \cdot 45$ \\
\hline & 20 & II 5 & I 745 & $12 \cdot 1$ & $2 \cdot 84$ \\
\hline \multicolumn{6}{|c|}{ After 2 weeks } \\
\hline \multirow[t]{4}{*}{ Control } & 0 & 9I & r694 & $4 \cdot 3$ & $2 \cdot 27$ \\
\hline & 5 & 103 & 1807 & $8 \cdot 7$ & $2 \cdot 73$ \\
\hline & 10 & 108 & 1818 & $7 \cdot 6$ & 2.99 \\
\hline & 20 & I 26 & I 765 & $8 \cdot 4$ & $3 \cdot 18$ \\
\hline \multirow[t]{4}{*}{ Thyroxine } & 0 & 90 & I 764 & $7 \cdot 9$ & I.55 \\
\hline & 5 & 97 & 1903 & $7 \cdot 1$ & $1 \cdot 74$ \\
\hline & 10 & I I I & 1747 & II.7 & $2 \cdot 75$ \\
\hline & 20 & 177 & I 553 & $9 \cdot 4$ & $2 \cdot 85$ \\
\hline
\end{tabular}

Expt 2. Since vitamin A mobilization is dependent on growth, casein was used as a protein source: casein is a deficient protein for chicks and reduced growth was expected. However, no growth at all was obtained during the experimental period even on the $20 \%$ casein level. Though no full explanation of this fact can be given, the following points may be noted: $(a)$ the inhibition of growth on this diet was 

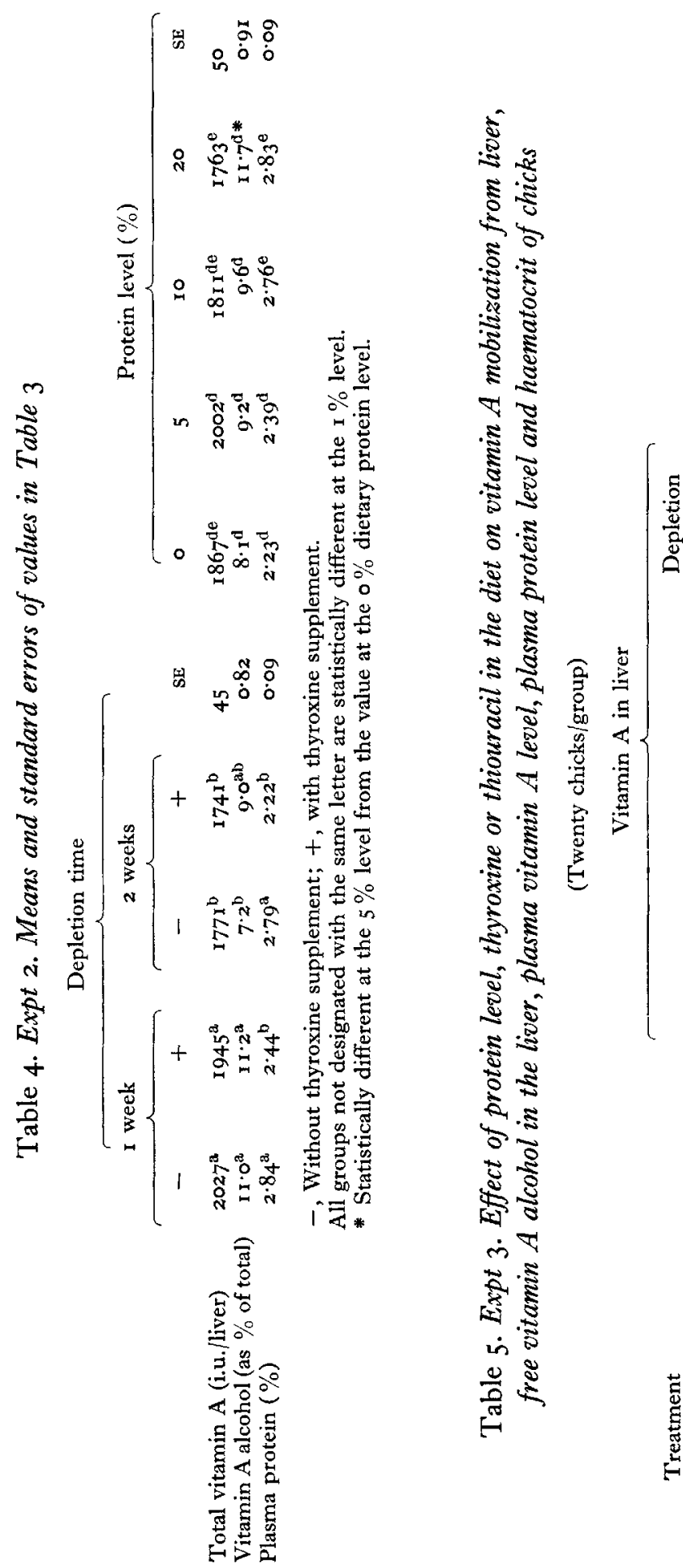

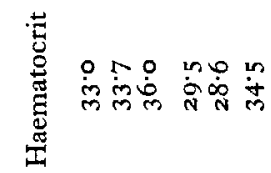

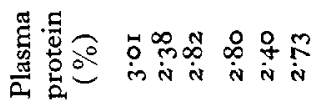

的高

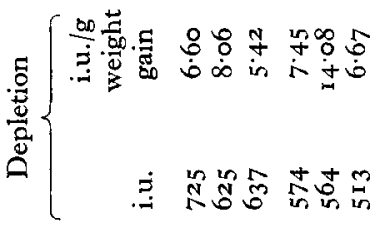

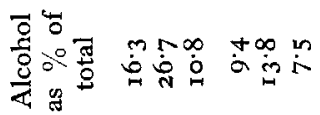

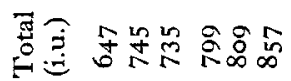

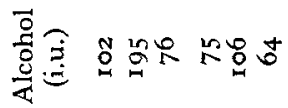

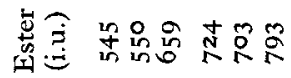

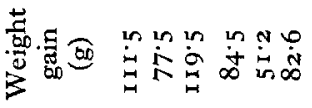

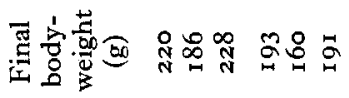

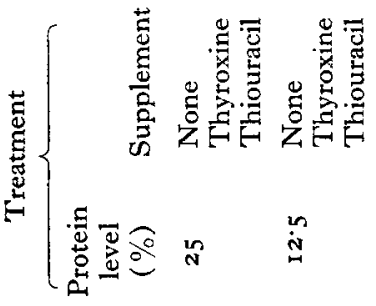


confirmed when the same diet was used on another occasion; $(b)$ casein from different commercial sources can have quite different biological values. This has been observed in our laboratory with insect larvae (I. Ishaaya, personal communication) and elsewhere in turkey chicks (Professor M. L. Scott, Department of Poultry Husbandry, Cornell University, personal communication). It seems that for chicks the casein from the source used in this experiment had a particularly low value.

The results presented in Tables 3 and 4 confirm that vitamin A mobilization from the liver increases with the level of dietary protein, but the tendency was not as clearcut as in the previous experiment: in the thyroxine-treated group, the diet with $5 \%$ protein caused less mobilization than the protein-free diet, after both 1 and 2 weeks of treatment; on the other hand, the control group given the protein-free diet retained a low amount of vitamin in the liver. These anomalies are probably due in part to the small size of the groups which had to be used in the experiment.

The percentage of vitamin A present in the liver in the alcohol form tended to increase with the level of protein (Table 4 ).

There was no significant effect of thyroxine on the percentage of vitamin A present in the liver in the alcohol form, or on the mobilization of the vitamin from the liver. As expected, the plasma protein content decreased concomitantly with the reduction in dietary protein. Thyroxine also lowered the level of the plasma protein, and its effect was superimposed on that caused by the reduction of dietary protein: its effect was more marked at the lower protein levels, causing a reduction of 32 and $36 \%$ at the 0 and $5 \%$ protein levels respectively, whereas at the two higher levels the reduction was only of 8 and 10 $\%$ after 2 weeks.

Expt 3. The results are shown in Tables 5 and 6. Liver vitamin A was depleted at a faster rate on the high protein intake. Thiouracil decreased vitamin A removal from the livers at both the high and low protein levels. The group given the thiouracil supplement and the $25 \%$ protein level gained $8 \mathrm{~g}$ more in weight and lost 88 i.u. vitamin A less than its control group. At the low protein level, the thiouracil-fed group made the same gain while using 58 i.u. vitamin $A$ less than its control group. These differences, even if not statistically significant, hint that this drug must have lowered the maintenance requirement for vitamin A. Thyroxine too caused a decrease in liver depletion, but in this instance inhibition of growth might explain it. When the weight gains were similar (as in the thyroxine-treated group given the high-protein diet and in the unsupplemented and thiouracil-treated groups given the low-protein diets), removal of vitamin A from the liver was greater in the thyroxine-fed group. Though it is recognized that part of this effect may have been due to the higher protein level, it seems that the hyperthyroid condition helped to increase vitamin A removal from the liver.

Low dietary protein content and thiouracil reduced the percentage of vitamin A in the alcohol form in the liver, whereas thyroxine increased it.

The ratio of vitamin A depletion from the liver to weight gain (i.u./g) may be essentially a reflection of growth rate. However, by comparing the values obtained some useful deductions can be made, namely that thyroxine increases and thiouracil decreases vitamin A removal from the liver. This ratio is correlated with the per- 
centage of vitamin A alcohol in the liver. Fig. I shows the two rectilinear relationships obtained with the different protein levels when the mean ratios for the treatments are plotted against the percentage of vitamin A alcohol in the liver. From these relationships it can also be seen that the low dietary protein level increased the gross vitamin A requirement for growth. Thyroxine increased and thiouracil decreased this requirement at both levels of dietary protein.

Table 6. Expt 3. Table of means and standard errors of values in Table 5

\begin{tabular}{|c|c|c|c|c|c|c|c|}
\hline \multirow[b]{2}{*}{ Tested variable } & \multicolumn{4}{|c|}{ Supplement } & \multicolumn{3}{|c|}{ Protein level } \\
\hline & None & Thyroxine & Thiouracil & $\mathrm{SE}$ & $12.5 \%$ & $25 \%$ & $\mathbf{S E}$ \\
\hline Weight gain (g) & $99^{\mathrm{a}}$ & $65^{b}$ & ror ${ }^{2}$ & $3 \cdot 6$ & $73^{d}$ & $106^{e}$ & 3.0 \\
\hline $\begin{array}{l}\text { Total vitamin A } \\
\text { (i.u./liver) }\end{array}$ & $717^{a}$ & $779^{\mathrm{a}}$ & $795^{a \S}$ & $21 \cdot 5$ & $764^{d}$ & $7 \operatorname{Ir}^{\mathrm{d}} \S$ & $17 \cdot 6$ \\
\hline $\begin{array}{l}\text { Vitamin A alcohol } \\
\text { (as } \% \text { of total) }\end{array}$ & $\mathrm{r}_{3} \cdot \mathrm{I}^{\mathrm{a}}$ & $20 \cdot I^{b}$ & $9 \cdot 2^{\mathrm{c}}$ & $I \cdot O$ & $10 \cdot 2^{d}$ & $17 \cdot 6^{8}$ & 0.8 \\
\hline $\begin{array}{l}\text { Vitamin A utilization } \\
\text { (i.u./g gain) }\end{array}$ & $7 \cdot 0^{\mathrm{a}}$ & II $4^{\mathrm{b}}$ & $6 \cdot 0^{c}$ & 0.21 & $9 \cdot 5^{d}$ & $6 \cdot 8^{e}$ & 0.17 \\
\hline $\begin{array}{l}\text { Plasma vitamin A } \\
\text { (i.u. } / 100 \mathrm{ml} \text { ) }\end{array}$ & $13^{8^{a}}$ & $157^{\mathrm{b}}$ & $13^{6^{a}}$ & $3 \cdot 6$ & $145^{\mathrm{d}}$ & $142^{d}$ & $2 \cdot 9$ \\
\hline Plasma protein $(\%)$ & $2 \cdot 91^{\mathrm{a}}$ & $2 \cdot 39^{\mathrm{b}}$ & $2 \cdot 77^{\mathrm{a}}$ & 0.09 & $2 \cdot 64^{\mathrm{d}}$ & $2 \cdot 73^{d}$ & 0.07 \\
\hline Haematocrit & $3 I \cdot 3^{a}$ & $31 \cdot 2^{a}$ & $35 \cdot 2^{\mathrm{b}}$ & 0.6 & $3 I \cdot 0^{d}$ & $34^{-2^{\mathrm{e}}}$ & 0.5 \\
\hline
\end{tabular}

All groups not designated by the same letter are statistically different at the $\mathbf{~} \%$ level.

$\S$ Statistically different at the $5 \%$ level from the value for the group without supplement or from the value for the group on the low-protein diet.

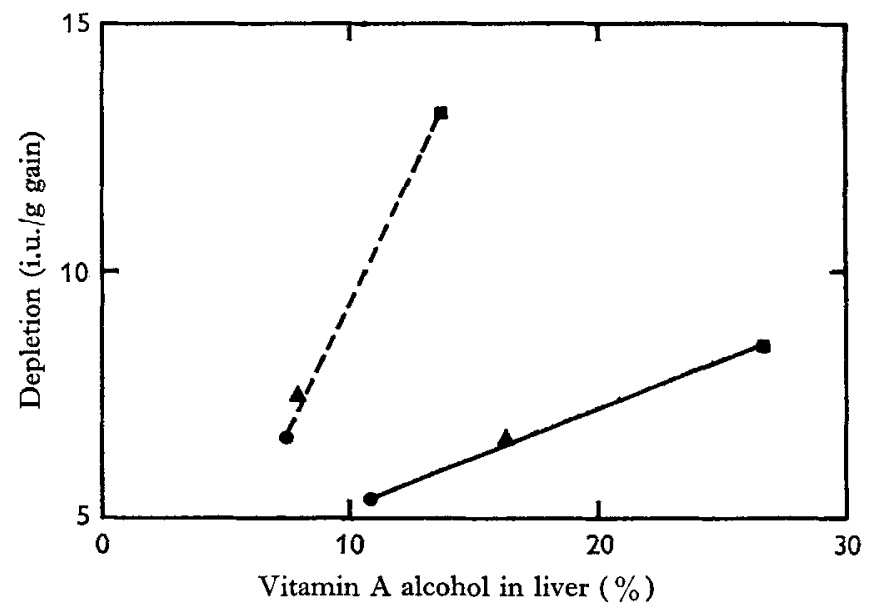

Fig. I. Expt 3. Mean values for vitamin A depletion (expressed as i.u. vitamin A/g weight gain) plotted against the corresponding mean values for percentage liver vitamin $\mathrm{A}$ content in the alcohol form. Each point represents the mean of twenty individual values for chicks given a diet containing 24 or $12.5 \%$ protein without supplement or supplemented with thiouracil or thyroxine. -, $25 \%$ protein;...$-12.5 \%$ protein; $\Delta$, control; $\boldsymbol{\bullet}$, thiouracil; $\mathbf{D}$, thyroxine.

Plasma vitamin A was affected neither by dietary protein level nor by thiouracil supplementation. Thyroxine caused a very marked rise $(36 \%)$ at the low protein level, but it had no effect at the $25 \%$ level. 
The level of dietary protein was reflected by the level of plasma protein. Thyroxine treatment lowered plasma protein content, but thiouracil had no appreciable effect. The haematocrit value was lowered by the low dietary protein level. Thiouracil increased the haematocrit value at both dietary protein levels, whereas thyroxine had no effect on it.
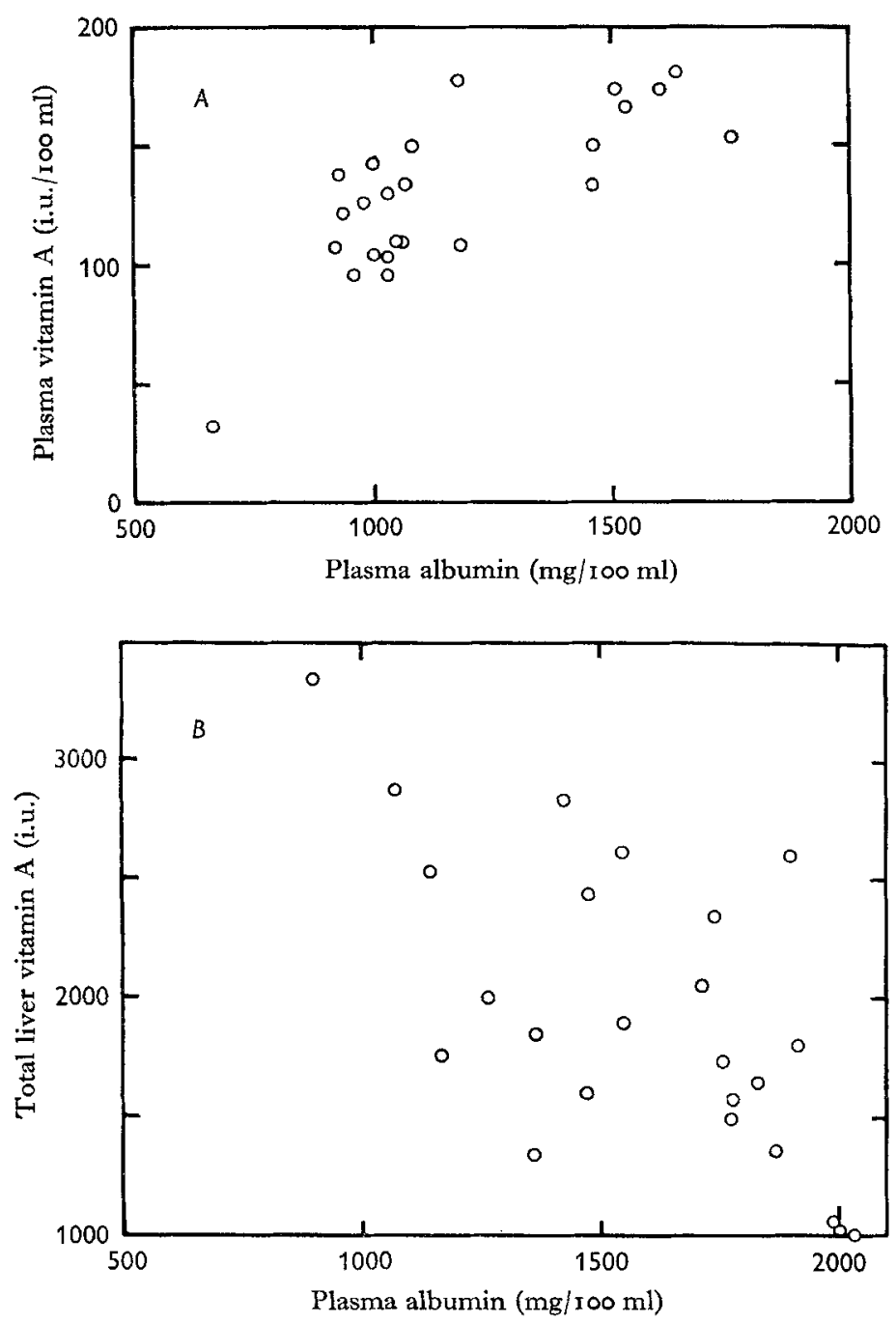

Fig. 2. Expt 4. Scatter diagrams showing the relation between plasma albumin level and $(A)$ plasma vitamin $A$ level and $(B)$ the amount of vitamin $A$ left in the liver after a 4-week depletion period for cockerels given a diet containing 22 or $5 \%$ protein.

Expt 4. The results are shown in Table 7. The plasma albumin and vitamin A contents were lowered by the low-protein diet during 2 weeks. The vitamin A level in plasma was related to the albumin level (Fig. $2 A$ ). Repletion with protein during 2 weeks raised plasma vitamin A and albumin to the control level. The downward trend of plasma vitamin $\mathrm{A}$ in the control group (Table 7) may be explained by the 
(ั)

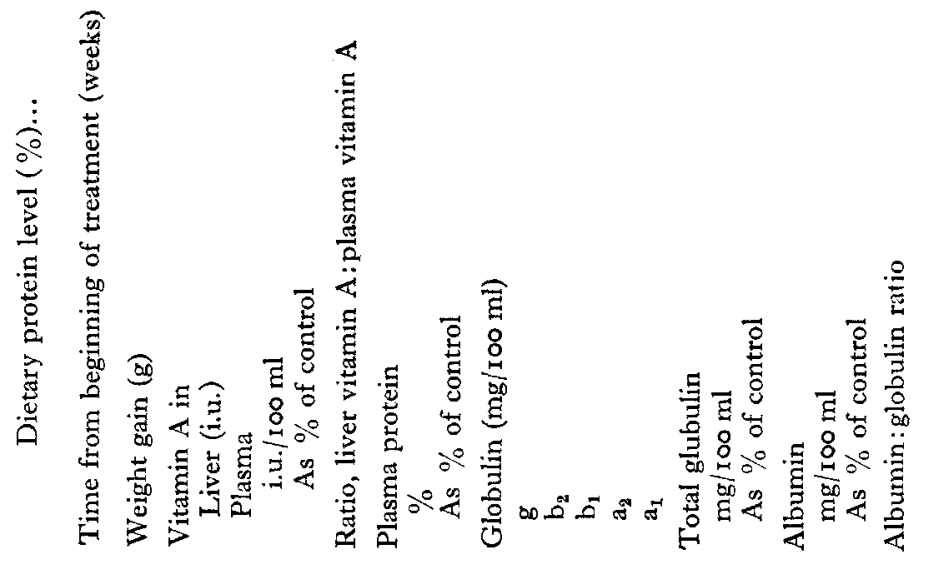


reduction of liver vitamin A stores caused by depletion during the first experimental period. In other work carried out in this laboratory (unpublished) it was found that, during depletion, plasma vitamin A content is correlated to liver vitamin A content: the latter decreased during a 5-week depletion period from 2200 to 40 i.u./liver, while plasma vitamin A decreased from 226 to 50 i.u./100 ml.

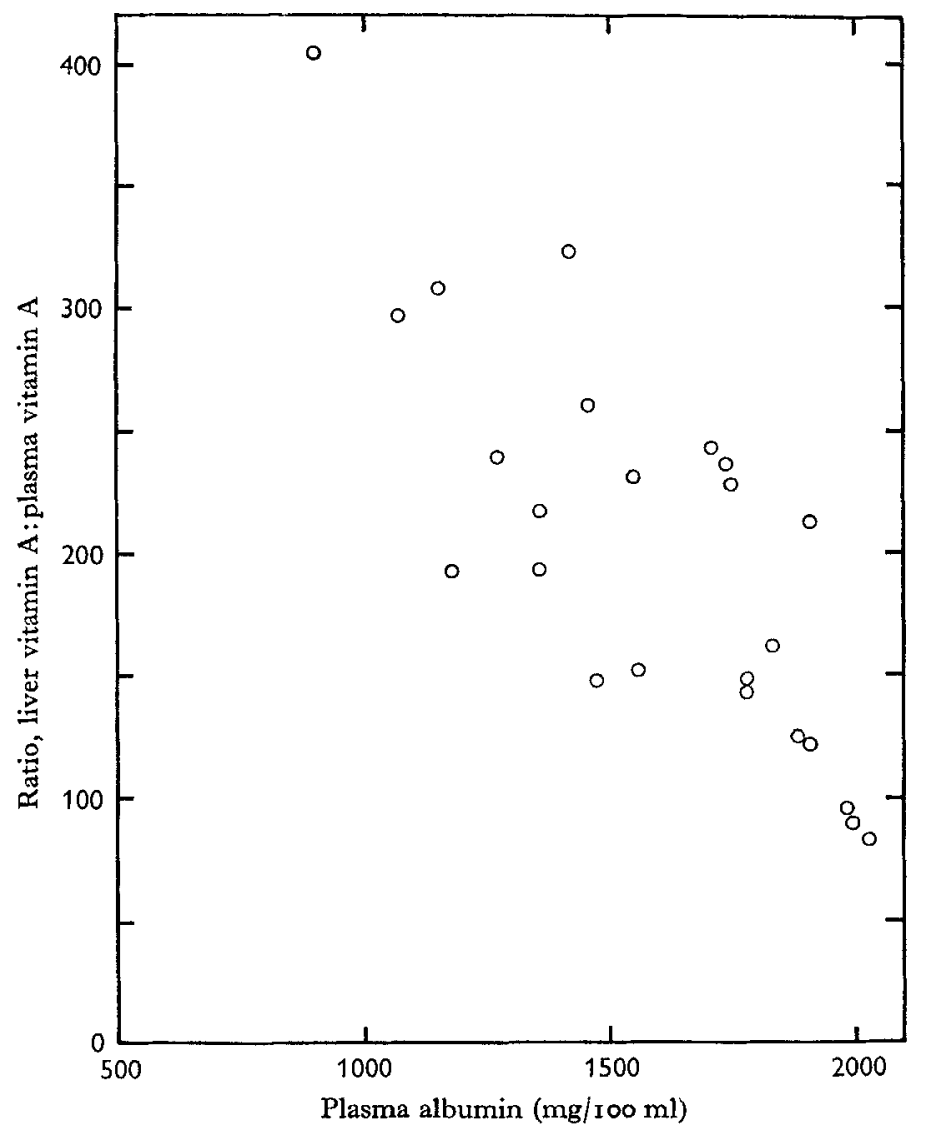

Fig. 3. Expt 4. Scatter diagram showing the relation between plasma albumin and the ratio, liver vitamin A: plasma vitamin A for cockerels given a diet containing 22 or $5 \%$ protein.

No significant differences were caused by the low-protein diet either in the total globulins or in the different globulin fractions. Vitamin A level in liver after 4 weeks' depletion was highest in the low-protein group. The high ratio of liver vitamin A content to plasma vitamin A content in the protein-depleted chicks $5 \%$ dietary protein level) emphasizes the low capacity of their blood to take up vitamin A from the liver. Plasma albumin content was found to be indirectly correlated with the amount of vitamin A left in the liver at the end of the experiment (Fig. $2 B$ ) and to the ratio of liver vitamin A content to plasma vitamin A content (Fig. 3). These correlations show that the albumin fraction obtained by electrophoresis may be concerned in vitamin $\mathrm{A}$ mobilization from the liver and its transport in plasma. 


\section{DISCUSSION}

The experiments here reported confirm that with vitamin A-deficient diets the rate of depletion of liver vitamin $A$ is affected by the level of dietary protein. Our findings are in agreement with the results obtained by Rechcigl et al. (1962) and Deshmukh et al. (1964) with rats. Low plasma vitamin A concentration in animals fed on a low-protein diet is believed to be caused by decreased concentration of agents carrying vitamin A in the plasma. Friend et al. (1961) found a close correlation between vitamin A and albumin level in plasma of pigs suffering from severe protein malnutrition. A similar correlation was observed by Arroyave et al. (1963) in rats. Our results with cockerels (Expt 4) agree with their reports. Here too, the level of plasma vitamin A was limited by the amount of carrying agent in the blood, and was not correlated with body reserves. In electrophoresis the plasma proteins transporting vitamin $\mathrm{A}$ ester and alcohol seem to behave in the same way as albumin, but other carrying agents, however, may be concerned. Vitamin A in blood has been said to be combined with different lipoproteins. Garbers, Gillman \& Peisach (1960) found that vitamin $\mathrm{A}$ alcohol in plasma is associated with the globulin fraction. It may well be that, owing to our less sensitive electrophoretic method, the $\alpha_{1}$-globulin fraction was included in our 'albumin'. A moderately low level (12.5\%) of dietary protein reduced the content of plasma protein but had no effect on vitamin A level in blood plasma. Supplementation with thyroxine of a diet containing an optimum level of dietary protein did not change the level of plasma vitamin A in spite of the lowered plasma protein level. When the diet contained a moderately low level of protein, supplementation with thyroxine caused a significant increase of plasma vitamin A in spite of plasma protein being lowered still further. From these observations it may be concluded that though lowering of plasma protein (or probably of its albumin fraction) hinders vitamin A mobilization from the liver, it is only one of the factors concerned in vitamin A utilization. A new aspect which appears from our findings is that the rate of liver depletion is closely related to the percentage of liver vitamin A found in the alcohol form: an increased percentage of vitamin $\mathrm{A}$ in the alcohol form in the livers of hyperthyroidic chicks was related to a greater depletion of vitamin A from their livers. Hypothyroidism caused by thiouracil lowered the percentage of vitamin A alcohol and reduced liver depletion. Deshmukh et al. (1964) showed that the activities of enzymes of the pancreas and intestinal mucosa hydrolysing and synthesizing vitamin A ester decreased progressively with the lowering of dietary protein level. They found the same trend also in the changes of the liver enzyme oxidizing retinene. Changes in the levels of these enzymes may possibly explain our finding that the percentage of vitamin A alcohol is considerably decreased by a lowering of the dietary protein level. The changes brought about by hyper- and hypo-thyroidism in the percentage of vitamin A alcohol in liver may also be due to changes in the levels of the same enzymes. Work to check this hypothesis is being carried out at present in this laboratory.

Protein malnutrition had no effect, during a I-month experimental period on plasma globulins determined by electrophoresis. This finding is in contrast with the state- 
ment of Vakil, Roels \& Trout (1964) that the content of $\gamma$-globulin was increased in protein-deficient rats. Their rats received a protein-free diet, but in our experiment a $5 \%$ protein level was used. However, a species difference would seem a more plausible explanation.

This work was financed by grant no. FG-Is-135 from the US Department of Agriculture.

\section{REFERENCES}

Ames, S. R., Risley, H. A. \& Harris, P. L. (x954). Analyt. Chem. 26, I378.

Arnrich, L. \& Morgan, A. F. (1954). Y. Nutr. 54, 107.

Arroyave, G., Wilson, D., Méndez, J., Béhar, M. \& Scrimshaw, N. S. (196r). Am. F. clin. Nutr. 9, I80.

Arroyave, G., Wilson, D., Contreras, C. \& Béhar, M. (г963). F. Pediat. 62, 902.

Ascarelli, I., Budowski, P., Nir, I. \& Bondi, A. (I964). Poult. Sci. 43, 370.

Babaev, T. A. (1963). Vop. med. Khim. 9, 261.

Bagchi, K., Halder, K. \& Chowdhury, S. R. (I959). F. Indian med. Ass. 33, 401.

Basu, N. M. \& De, N. K. (I941). Sci. Cult. 6, 672.

Baumann, C. A., Foster, E. G. \& Moore, P. R. (1942). F. biol. Chem. 142, 597.

Cama, H. R. \& Goodwin, T. W. (1949). Biochem. F. 45, 317.

Chanda, R., Clapham, H. M., McNaught, M. L. \& Owen, E. C. (I952). Biochem. F. 50, 95.

Deshmukh, D. S., Malathi, P. \& Ganguly, J. (1964). Biochem. \%. 90, 98.

Deuel, H. J. Jr., Hrubetz, M. C., Johnston, C. H., Rollman, H. S. \& Geiger, E. (1946). F. Nutr. 31, I 87.

Dye, M., Bateman, I. \& Porter, T. (1945). F. Nutr. 29, 34 I.

Esh, G. C. \& Bhattacharya, R. K. (1961). Ann. Biochem. exp. Med. 21, 57.

Federer, W. T. (1955). Experimental Design. New York: MacMillan.

Fraps, G. S. (1946). Archs Biochem. ro, 485.

Friend, C. J., Heard, C. R. C., Platt, B. S., Stewart, R. J. C. \& Turner, M. R. (rg6r). Br. F. Nutr. I5, 231.

Ganguly, J., Krinsky, N. I., Mehl, J. W. \& Deuel, H. J. Jr. (1952). Archs Biochem. Biophys. 38, 275. Garbers, C. F., Gillman, J. \& Peisach, M. (1960). Biochem. F. 75, 124.

Gornall, A. G., Bardawill, C. J. \& David, M. M. (r949). \%. biol. Chem. r77, 75 I.

Grassman, W. (1956). Ciba Fdn Symp. Paper Electrophoresis, p. 2, London: J. and A. Churchill L.td. James, W. H. \& Elgindi, L. M. (1953). F. Nutr. 51, 97.

Johnson, R. M. \& Baumann, C. A. (1947). F. biol. Chem. 171, 5 I3.

Krinsky, N. 1., Cornwell, D. G. \& Oncley, J. L. (I 958). Archs Biochem. Biophys. 73, 233.

Moore, T., Sharman, I. M. \& Ward, R. J. (1952). Biochem. J. 52, xii.

Rechcigl, M. Jr., Berger, S., Loosli, J. K. \& Williams, H. H. (1962). F. Nutr. 76, 435.

Sokoloff, L. \& Kaufman, S. (1959). Science, 129, 569.

Sokoloff, L. \& Kaufman, S. (I960). Fedn Proc. Fdn Am. Socs exp. Biol. 19, 175.

Sokoloff, L. \& Kaufman, S. (I96r). F. biol. Chem. 236, 795.

Sokoloff, L., Kaufman, S., Campbell, P. L., Francis, C. M. \& Gelboin, H. V. (1963). F. biol. Chem. 238, 1432 .

Thompson, S. Y., Ganguly, J. \& Kon, S. K. (1949). Br. F. Nutr. 3, 50.

Vakil, U. K., Roels, O. A. \& Trout, M. (1964). Br. F. Nutr. 18, 2 I 7.

Wiese, C. E., Mehl, J. M. \& Deuel, H. J. Jr. (1948). F. biol. Chem. 175, 2 r. 